\title{
Resenha: The Transnational Capitalist Class
}

\author{
Por Ana Lucia Guedes *
}

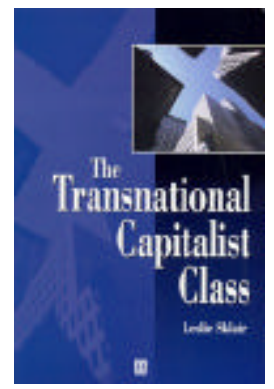

SKLAIR, Leslie. The Transnational Capitalist Class. Oxford: Blackwell, 2001. 335p.

ISBN 0-631-22461-0 (hc) ISBN 0-631-22462-9 (pc)

Segundo o autor, o propósito do livro é explicar como a classe capitalista transnacional transformou o capitalismo num projeto de globalização. Mais especificamente, Sklair se propõe a identificar empiricamente os membros e as instituições que compõem a classe capitalista transnacional e a definir o conceito de classe capitalista transnacional, recorrendo a uma teoria que se propõe a explicar o funcionamento do sistema capitalista global.

De um modo geral, a obra contribui para o debate acerca do fenômeno da globalização. De modo mais específico, cabe ressaltar que sua contribuição é inovadora por estar focada em um aspecto raramente levado em consideração: as corporações transnacionais. Sklair demonstra como a globalização funciona e se desenvolve pela perspectiva das corporações transnacionais, de seus aliados nas agências governamentais e da mídia.

Além disso, o autor explora a polarização de classes e a sustentabilidade ambiental, dois dos principais problemas decorrentes desse recente processo, e avalia as tentativas da classe capitalista transnacional para resolvê-los. Essa abordagem, focada naqueles que são responsáveis tanto por duas das principais crises globais quanto pelas tentativas para resolvê-las, resume em grande parte a contribuição teórica do autor. Sklair argumenta que ao contrário da maioria das contribuições conhecidas nesse âmbito, "a globalização é governada por atores identificáveis, que trabalham por meio de instituições que eles possuem e/ou controlam" (p.1).

$\mathrm{Na}$ introdução, o autor define os conceitos básicos que constituem sua proposição teórica sobre o fenômeno da classe capitalista transnacional. Ele argumenta que "transnacional" se refere a forças, processos e instituições que transcendem fronteiras, mas cujos poderes e autoridade não derivam do Estado. Mais especificamente, a teoria do sistema global, proposta pelo autor, indica que as mais importantes forças transnacionais são as empresas transnacionais, a classe capitalista transnacional e a cultura-ideologia do consumerismo.

$\mathrm{O}$ autor argumenta que o poder e a autoridade dos membros da classe capitalista transnacional derivam das corporações transnacionais que possuem e controlam. Essa nova classe capitalista transnacional é composta por executivos de corporações, burocratas, políticos, profissionais globalizados e elites consumeristas. Sklair define a cultura-ideologia do consumerismo como um conjunto de crenças e práticas que convence as pessoas de que consumir além da satisfação das necessidades físicas é o núcleo da existência. Por conseguinte, a teoria do sistema global é baseada no conceito de práticas transnacionais, isto é, práticas que atravessam as fronteiras do Estado, mas que não se originam em agências ou atores estatais. Analiticamente, o autor demonstra que essas práticas operam em três esferas: a econômica, a política e a cultural/ideológica.

O livro está estruturado da seguinte forma: no primeiro capítulo (chamado de introdução), define os conceitos e as quatro proposições que ligam a teoria do sistema global ao conceito de classe capitalista transnacional. A

* Professora Titular e Pesquisadora da Escola Brasileira de Administração Pública e de Empresas da Fundação Getulio Vargas. Ph.D. em Relações Internacionais, pela London School of Economics and Political Science (LSE), 1998. Mestre em Relações Internacionais, pela Pontifícia Universidade Católica do Rio de Janeiro (PUC-Rio), 1993. Bacharel em Administração, pela Universidade Estadual de Maringá (UEM), 1985. E-mail: guedes@ fgv.br. 
primeira proposição a é de que "uma classe capitalista transnacional com base nas corporações transnacionais está emergindo e está mais ou menos no comando do processo de globalização" (p.5). A segunda proposição é a de que "a classe capitalista transnacional está começando a agir como uma classe dominante transnacional, em algumas esferas" (p.5). A terceira proposição faz a conexão entre capitalismo e consumerismo, ao afirmar que "a globalização do sistema capitalista reproduz a si mesmo por meio da cultura-ideologia do consumerismo direcionada para o lucro" (p.6). Devido às crises resultantes das contradições de um sistema que maximiza lucros privados, a quarta proposição sustenta que "a classe capitalista transnacional está trabalhando conscientemente para resolver duas crises centrais, que são a simultânea criação de elevada pobreza e elevada riqueza dentro e entre comunidades e sociedades (a crise de polarização de classes) e a insustentabilidade do sistema (a crise ecológica)".

No segundo capítulo, o autor propõe um modelo de classe capitalista transnacional e a sua relação com outros grupos dentro do sistema capitalista global. No terceiro capítulo, elabora uma classificação da economia global por meio das corporações que a dominam. Nesse capítulo, consta a metodologia utilizada pelo autor para a realização de pesquisa empírica em 80 corporações transnacionais. Os resultados evidenciam o processo de globalização seguido por essas empresas. Com base nesses resultados, Sklair define e passa a mensurar o fenômeno da globalização a partir de quatro critérios: investimento direto externo, melhores práticas mundiais (benchmarking), cidadania corporativa e visão global. É nessa ordem que esses critérios são tratados nos cinco capítulos seguintes.

Finalmente, no nono capítulo, Sklair resume o argumento do livro com base nas quatro proposições apresentadas na introdução. Afirma, então, que uma classe capitalista transnacional está emergindo, e que esta age como uma classe dominante transnacional em algumas esferas, abastecida pela cultura-ideologia do consumerismo, a qual, por sua vez, é orientada pelo desejo insaciável dos capitalistas por lucro e pela necessidade do sistema de expansão contínua. $\mathrm{O}$ autor acrescenta que a classe capitalista transnacional está conscientemente trabalhando para resolver os principais impasses do capitalismo global, que são a crise de polarização de classes e a crise ecológica, ainda que continue falhando nessa tarefa.

Sklair conclui que a resistência à globalização do capitalismo deve ser guiada pela busca de uma transição pacífica para outras formas de organização local e global que podem reverter a tendência do sistema em direção às crises de polarização de classes e de sustentabilidade ambiental. Nesse sentido, o autor entende que a questão da democracia é central para as práticas e para o sucesso dos movimentos sociais contra esse tipo de capitalismo. No entanto, não fornece nenhuma explicação mais detalhada de como tal processo de democratização poderia interferir no sistema capitalista.

Apesar da dificuldade que alguns acadêmicos da área de administração possam ter quanto à escolha do autor por uma perspectiva crítica em relação às empresas transnacionais, sua obra não deve ser negligenciada, em face da sua contribuição para o entendimento das práticas de um dos atores mais relevantes no contexto internacional contemporâneo, as empresas transnacionais. Ao mesmo tempo em que Sklair identifica os estudos normativos e prescritivos produzidos pela comunidade empresarial internacional como "literatura promocional", ele não invalida os esforços feitos ao longo das últimas décadas na área de ambientalismo corporativo (conforme dados apresentados no sétimo capítulo). Como ele mesmo afirma, pode parecer paradoxal para positivistas sem ser surpreendente para os dialéticos, que as mesmas forças transnacionais que promovem a globalização servem também para minimizá-la.

Desta forma, recomendo a leitura desta relevante obra para estudantes e pesquisadores da área de administração, cujas práticas estejam focadas em empresas transnacionais. Tal leitura implica não somente na desmistificação do fenômeno da globalização, mas principalmente na construção de uma visão mais realista e crítica de um dos principais fenômenos contemporâneos.

Por último, mas não menos importante, sugiro aos leitores que não estejam familiarizados com métodos e técnicas de pesquisa em sociologia, uma breve consulta aos anexos da obra. O primeiro anexo contém a lista das empresas entrevistadas com base no ranking da publicação Fortune Global 500, e o segundo relaciona as demais fontes, dentre corporações e organizações, que foram entrevistadas. A apresentação dessas fontes confirma a preocupação inicial do autor de sustentar seus argumentos teóricos em evidências empíricas. 